\title{
STUDIES IN IRON TRANSPORTATION AND METABOLISM. II. THE MECHANISM OF IRON TRANSPORTATION : ITS SIGNIFICANCE IN IRON UTILIZATION IN ANEMIC STATES OF VARIED ETIOLOGY ${ }^{1}$
}

\author{
BY CARL V. MOORE,2 CHARLES A. DOAN, AND WM. R. ARROWSMITH \\ (From the Department of Medicine, Division of Research Medicine, Ohio State \\ University, Columbus)
}

(Received for publication March 11, 1937)

A growing interest in the mechanism by which iron is transported in the blood stream has been stimulated by the desire to understand more fully this essential phase of iron metabolism in the mammalian body. With the clarification of this important detail a more complete understanding of normal erythropoiesis and of the iron deficiency states may be anticipated.

Despite a wide variety of observations reported in the literature, an entirely satisfactory and acceptable experimental definition of the manner in which iron transportation is effected has not as yet been presented. A. B. Macallum (1), Ehrlich and Lazarus (2), and Proescher and Arkush (3) observed that histologically many erythrocytes give an iron reaction. They assumed, therefore, that free iron, not identified with the hemoglobin molecule, is present in at least a portion of the red cells. Macallum postulated that iron is transported by the erythrocytes, and Proescher and Arkush further suggested that this may be accomplished through a loose combination with the lecithin of the erythrocyte corpuscular membrane. Other investigators (4 to 14) have studied the iron content of plasma and serum in the hope that some light might be shed on this problem of mineral transport, but their researches have not yielded conclusive information. Barkan $(15, a$ and $b$ ) has assigned to the "easily split-off" blood iron fraction the function of iron transportation and considers plasma iron as the medium of exchange between the tissues and " easily

\footnotetext{
1 Presented in part before the twenty-eighth Annual Meeting of the American Society for Clinical Investigation, May 4, 1936, at Atlantic City, New Jersey.

2 These studies were begun during the tenure of a $\mathrm{Na}$ tional Research Council Fellowship in the Department of Medical and Surgical Research, Ohio State University, and continued during the holding of an Eli Lilly Fellowship.
}

split-off " iron. Dominici (16) has stated his belief that serum iron, iron adsorbed to red cells, and the iron present in leukocytes, all constitute iron in the process of transportation by the blood stream.

The statement has been made in the first paper of this series (17) that according to current opinion, at least three different forms of blood iron must be considered: hemoglobin iron, plasma or serum iron, and "easily split-off" iron. The physiological function and the chemical nature of hemoglobin iron are well established; but for neither of the other two is this true (see Figure 1). That the small amount of iron present as such in normal serum (50 to 180 micrograms per cent for humans) is not dialyzable, and, therefore, is not in an ionized state, is known. Nothing else is certain. It is probably trivalent, is most likely in organic combination, and is present possibly as a complex ion. The two chief views relating to its function have been intimated in the preceding paragraph. The case for "easily split-off" iron is even more perplexing. It is so termed because it is readily separated by the action of dilute acids and bases from its lightly bound state within or in association with the erythrocytes. Different concentrations of hydrochloric acid, however, " splitoff" different amounts of iron (17), and both sulfuric and nitric acids "split-off" considerably greater quantities than does hydrochloric acid. Barkan and Berger observed (18) that saturation of blood with carbon monoxide "bound" about 60 to 70 per cent of the total "easily split-off" iron fraction in such a way as to protect it from the dissociating action of hydrochloric acid. Barkan (19) has presented considerable experimental evidence tending to show that " easily splitoff " iron is an organic, non-hemoglobinous form of iron. He is of the opinion that it is intimately linked with the function of iron transport. 


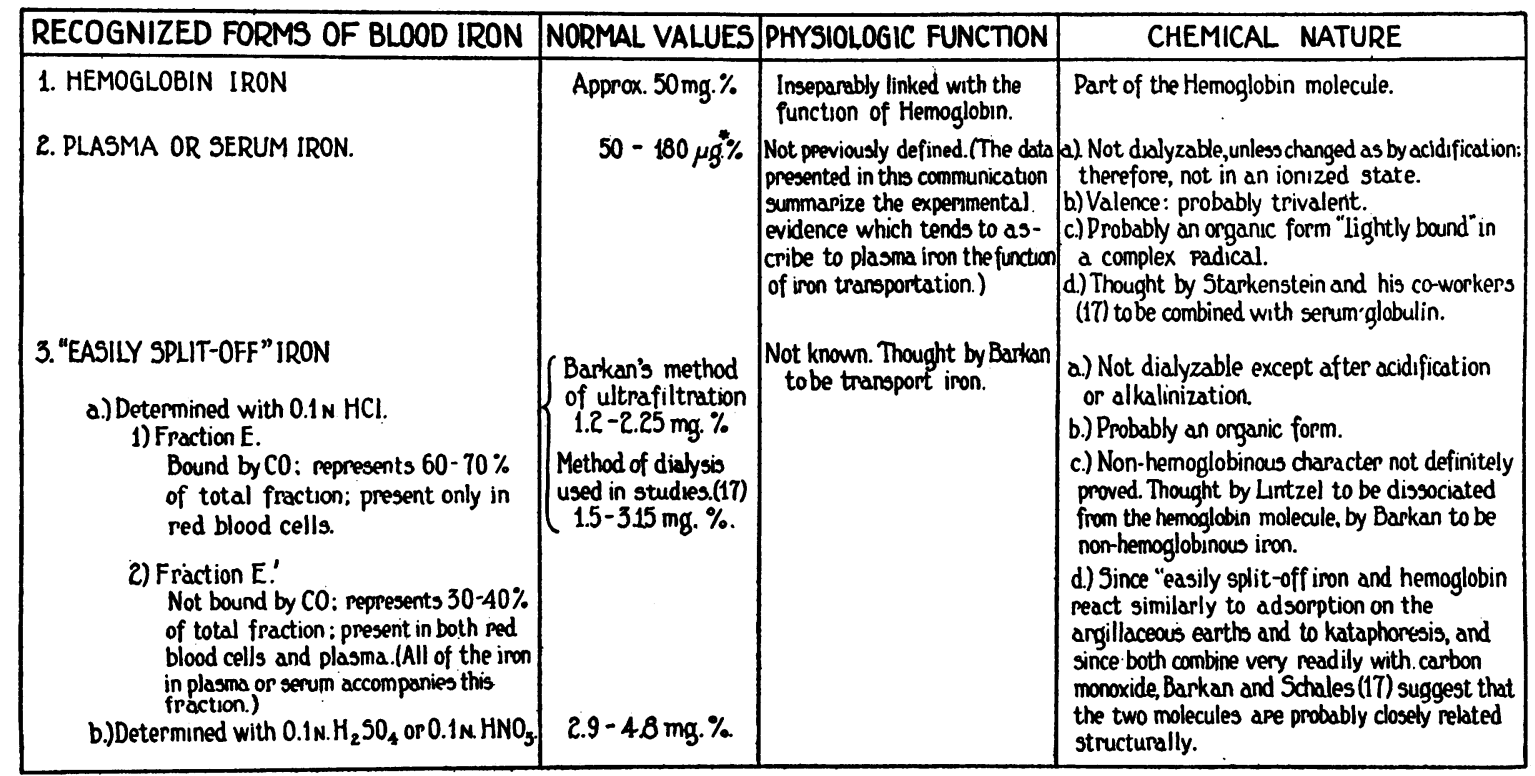

$\mu g=$ micrograms.

FIG. 1

Lintzel $(20, a$ and $b)$ on the other hand, has repeatedly been able to "split-off" equivalent amounts of iron from preparations of crystalline hemoglobin, and so has come to feel that "easily split-off " iron is dissociated from the hemoglobin molecule itself. In spite of the confused state of our knowledge concerning the source, chemical nature, physiological interrelationships, and actual identity of "easily split-off" iron, there can be no doubt that with the methods discussed in the preceding paper (17) a definite fraction of the blood iron, constant for any individual blood specimen, can be dissociated and accurately determined.

Since there are two forms of blood iron (serum iron and " easily split-off" iron) for which physiological functions have not been established definitely, it is logical to assume that, as, or in association with, one of them the transportation of iron in the blood stream may be effected. The present investigation represents an attempt to test the correctness of this assumption and to identify transport iron by following the responses both of the plasma and of the "easily split-off" iron values under the following conditions: 1 , following various exogenous and endogenous stimuli which influence the rate of absorption of iron from the gastro-intestinal tract; 2 , during varia- tions in the rate of iron utilization by the bone marrow in its synthesis of hemoglobin; 3 , with varying adequacy of the iron reserves in the body; and 4, in the presence of red cell destruction.

\section{Effect of the oral administration of iron salts on plasma and "easily split-off" blood iron}

Thoenes and Aschaffenburg (12) and Bing, Hanzal, and Myers (21) have reported increases in serum iron following single doses by mouth of various of the iron salts. Marlow and Taylor (5) failed to observe any change after the administration of six grams of iron and ammonium citrate, but the normal plasma iron values ( 0.4 to $0.7 \mathrm{mgm}$. per cent) obtained by these workers were several times higher than those reported by the majority of investigators (17) and were as high as those obtained at the very peak of the absorptive phase in the experiments of Thoenes and Aschaffenburg and of Bing, Hanzal, and Myers.

Using the methods previously reported (17), we have followed both the serum and "easily split-off " iron values for 24 hours after the oral administration in selected individuals of a single dose of iron. Reduced iron, ferrous ammonium sulphate, iron and ammonium citrate, ferrous 
glutamate, and ferric pyrophosphate have been used in varying dosage. Blood samples were withdrawn for analysis before the ingestion of iron and at $1,2,4,6,9,12$, and 24 hours thereafter. Increases in the serum iron concentration to from three to ten times the basal level were usually observed, while the minimal change noted in " easily split-off" iron occurred as a reflection of the serum iron increase. Data from a representative experiment are recorded in Figure 2. The subject in this instance was a 28 year old "normal" white male. Ten grams of iron and ammonium citrate were given and within 2 hours the serum iron had risen from its initial level of 100 micrograms per cent to 285 micrograms per cent. At 4 hours, the peak of 365 micrograms

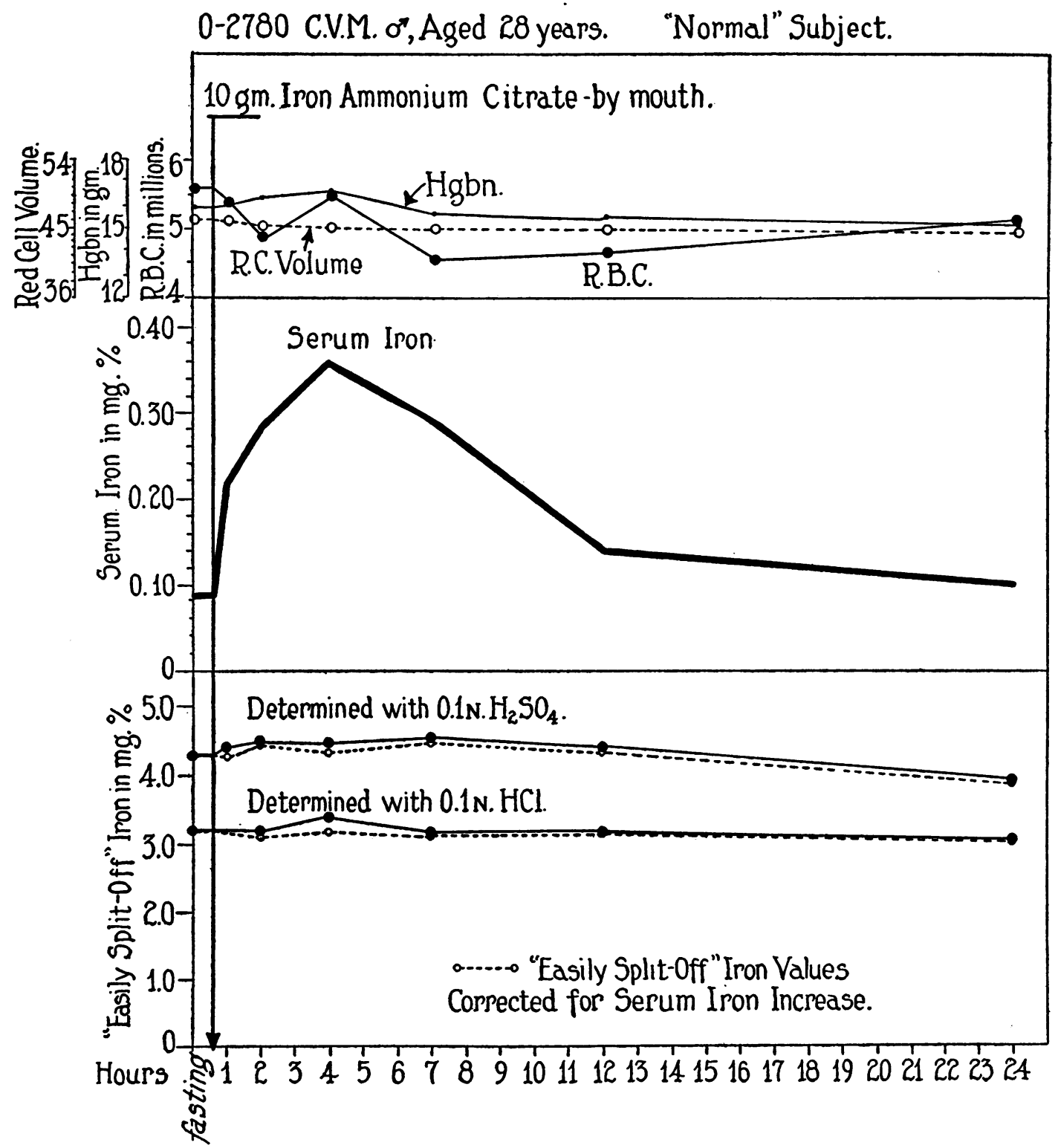

Fig. 2. Serum Iron and "Easily Split-off” Iron Curves During a Twenty-four Hour Period Following the Ingestion of 10 Grams of Iron and Ammonium Citrate

The iron absorption is clearly reflected in the serum iron fraction. The only increase in "easily split-off" iron occurred as a result of the serum iron increase (note corrected values). 
per cent was reached. When correction was made for this serum iron response, it was evident that no significant change had occurred in the " easily split-off" iron fraction. In general, the rise in serum iron usually began within the first half hour, reached its maximum at the end of 2 to 5 hours, and then fell gradually to reach the basal level at the end of 8 to 12 hours. The highest values obtained were in the neighborhood of 600 micrograms per cent.

Significant increases in serum iron were observed following iron and ammonium citrate in single doses varying from 2 to 20 grams. One normal subject (V. C., a young woman aged 26 years with normal gastric acidity) failed to show any serum iron response to 0.5 gram of reduced iron, but had a substantial rise (128 to 345 micrograms per cent) after 5 grams. A series of observations were made on Patient E. B., a 25 year old nurse in whom a diagnosis of hypochromic microcytic anemia with achlorhydria (histamine refractory) had been made. Two years before the studies here referred to were begun, the patient had responded to adequate iron therapy with a typical reticulocyte response and rise in hemoglobin. Upon discontinuing therapy, however, the hemoglobin gradually fell to the original low level again. Five grams of reduced iron were given (October 13,1934), and the serum iron rose from its base line level of 45 micrograms per cent to a peak of 255 micrograms per cent at the end of 5 hours. Two weeks later (October 31, 1934), without any intervening therapy having been given, the study was repeated except that 50 cc. $1 \mathrm{~N} \mathrm{HCl}$ were given with the 5 grams of reduced iron. At this time, the serum iron rose from approximately the same initial level to a high of 400 micrograms per cent at the end of two and one-half hours, and this high level was maintained for at least four additional hours.

Measurements of the blood iron changes following the oral administration of iron salts have been made on more than twenty subjects, and among these only three have failed to show increases in the plasma or serum iron concentration. One of the exceptions was a middle aged white male acutely ill with a rare mycotic infection. The second was a 55 year old retired physician who was, at the time of the observation, in an aleukemic phase of chronic myelogenous leukemia.
Both of these men received 15 grams of iron and ammonium citrate in one dose; both had normal gastric acidity. The third patient was a 38 year old colored female with achylia gastrica and typical pernicious anemia in relapse. She failed to show an increase in her serum iron level after 4 grams of reduced iron alone, and also after 4 grams of reduced iron given with $30 \mathrm{cc} .1 \mathrm{~N} \mathrm{HCl}$. With the reduced iron increased to 6 grams and acidified, however, a 50 per cent increase over the basal serum iron value did occur. All three of these patients were acutely ill at the time the observations were made. Any reason otherwise for their failure to respond, as did the rest of the subjects, is not at present apparent.

The observation that, following the oral administration of iron salts, serum iron is the only iron fraction to increase significantly in the blood during the phase of intestinal absorption, is in agreement with certain in vitro observations of Starkenstein and Weden (14) and of Barkan $(15, a ; 22)$. These workers added graded amounts of various of the iron salts to whole blood in vitro and found that invariably all of the added iron could subsequently be recovered from the plasma; no increase in iron occurred in association with the cells. Barkan (22) further noted that when iron salts were added to plasma or whole blood outside of the body, the iron was changed so that it would no longer pass through a semi-permeable membrane-unless acidified. Similarly, in our experiments, the increased iron in the plasma presumably the result of absorption from the gastro-intestinal tract was in an unionized state and could not be dialyzed through a cellophane membrane.

\section{The iron fractions of the blood in iron deficiency states}

In the iron deficiency anemias of varied etiology, we have found the serum iron values (see Table I) to be definitely lower (15 to 40 micrograms per cent) than the zonal range for normal. Similar results have been obtained by Locke, Main and Rosbash (11) in rabbits made anemic by repeated hemorrhages and in a few patients with iron deficiency anemias. Thoenes and Aschaffenburg (12) report low serum iron values in nutritional deficiency in children. Barkan (23) had opportunity to study the plasma iron level in 
TABLE I

Serum iron and "Easily split-off" iron in clinical states of varied etiology

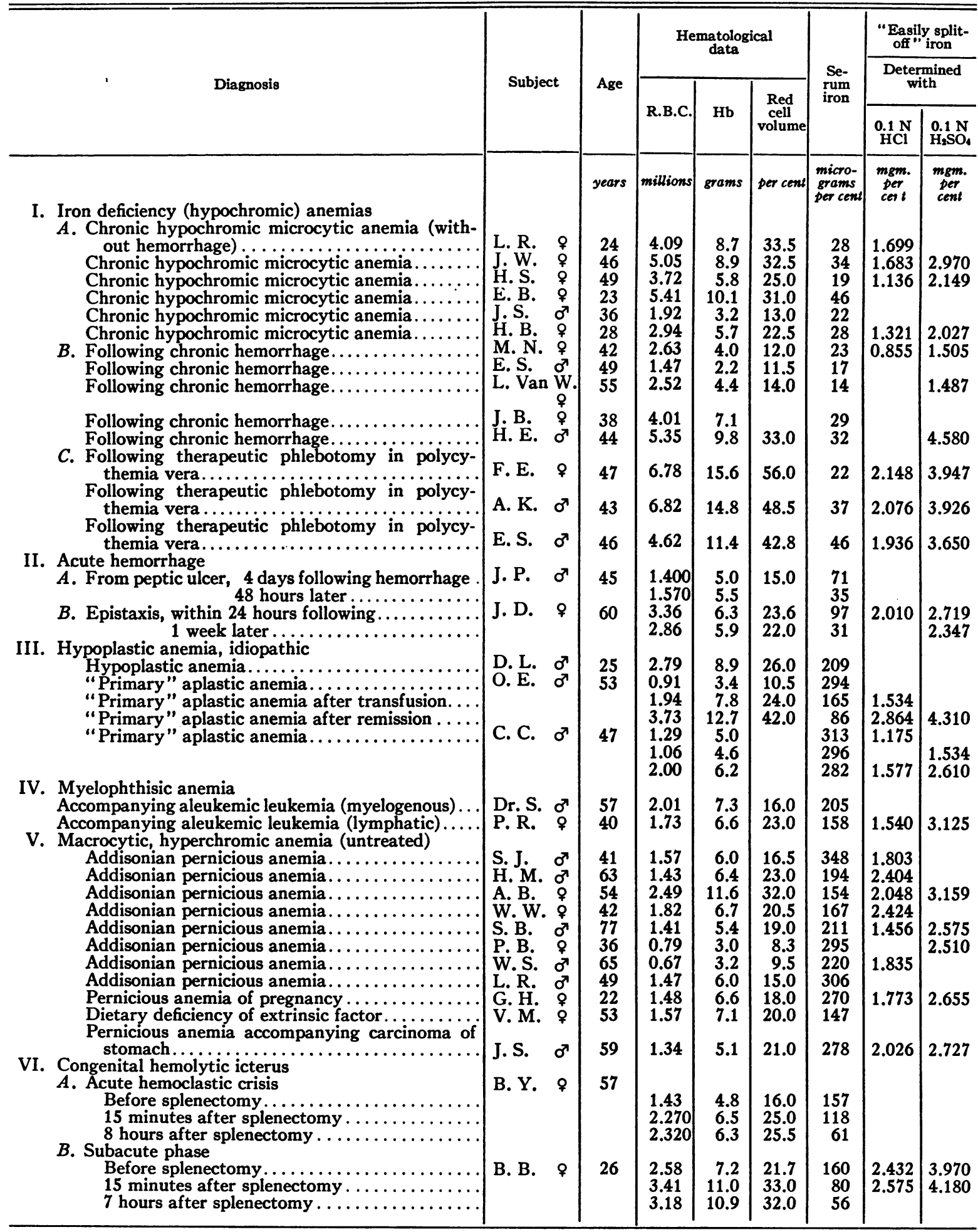


TABLE I-Continued

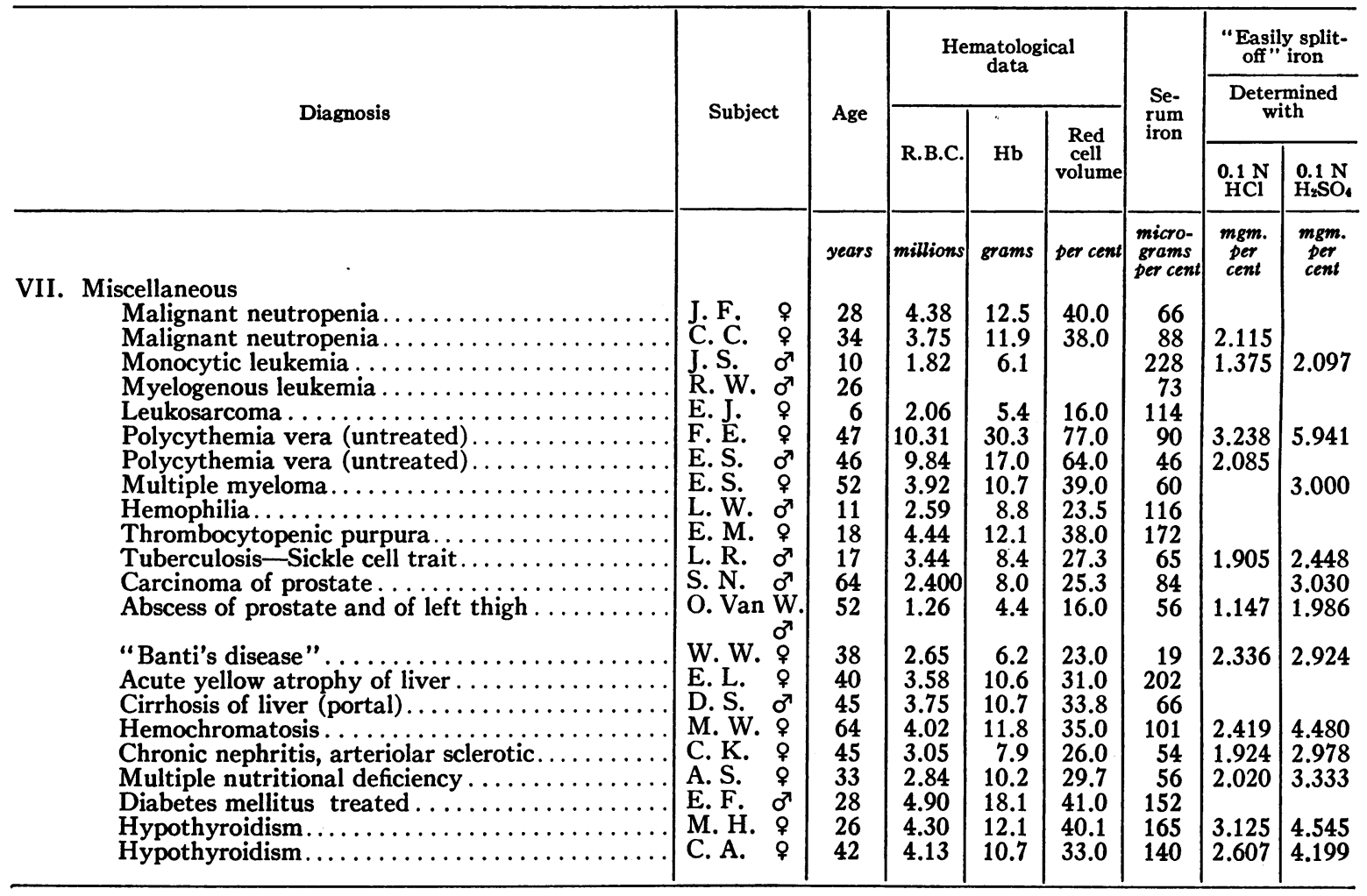

horses from the Serum Institute of Dorpot in whom anemias had developed following frequent bleedings over a long period. The plasma iron values in these animals were higher, not lower, than normal. What complicating factors, if any, such as liver or marrow damage, may have been present in these "serum-producing" animals to alter further their iron metabolism and thus cause the plasma iron levels to be high, are, of course, not known.

The "easily split-off" iron values, on the other hand, showed, in our series of cases, no consistent change. High normal as well as low and lower than normal figures were obtained. Barkan $(15, a)$ observed that the oral administration of iron to rabbits for one to two weeks failed, with one exception, to cause any increase in the " easily split-off" blood iron. The exception occurred in the case of an animal whose initial "easily split-off" iron level was lower than the average $(0.840 \mathrm{mgm}$. per cent); an increase to $1.400 \mathrm{mgm}$. per cent was obtained.
In order that the blood iron relationships in human iron deficiency states might be understood more completely than is possible from isolated single determinations in different patients, serial studies of serum and " easily split-off" iron were made in a number of selected individuals with hypochromic anemia over extended periods with and without iron therapy. The data from two representative cases is summarized in Figures 3 and 4. The first of these (Figure 3 ) presents the observations made on E. R., a young woman, 25 years old, with hypochromic microcytic anemia and hypochlorhydria. Following the oral administration of 6 grams of reduced iron in one dose, her'serum iron rose from its initial low level of 40 micrograms per cent to a peak value slightly over 500 micrograms per cent. After this initial observation, the patient was placed on a daily dose of 4 grams of iron pyrophosphate. A reticulocyte response (to 6 per cent) beginning on the sixth day of therapy was observed, and the hemoglobin gradually rose from its initial level of 9 grams per $100 \mathrm{cc}$. to 13 grams by the end of two 


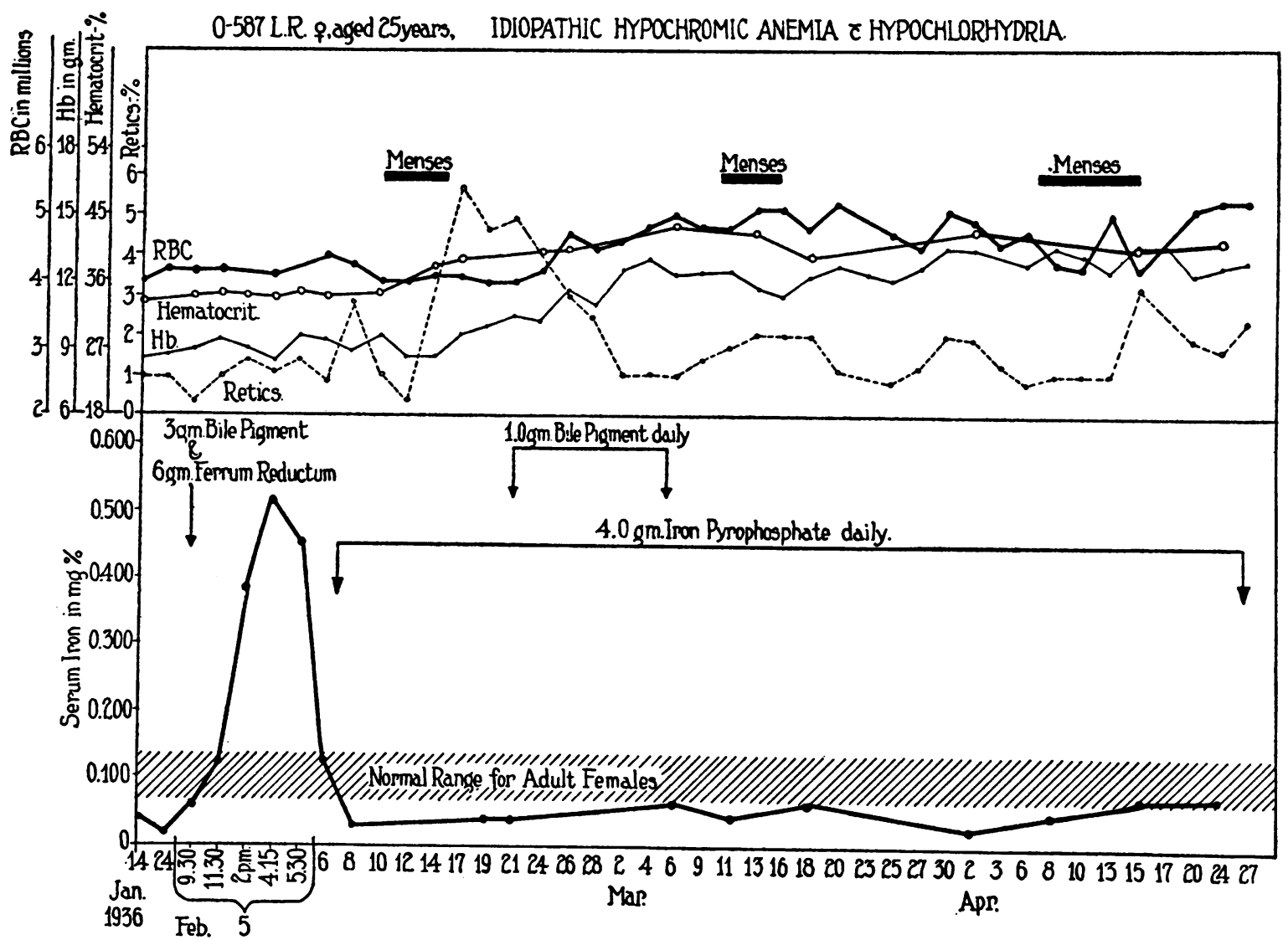

Fig. 3. Observations on the Serum Iron Level in a Patient with Hypochromic Microcytic Anemia During a Period of Intensive Iron Therapy

As an initial observation, a substantial rise in serum iron during the phase of intestinal absorption following a single large dose of ferrum reductum was demonstrated. The postabsorptive level of serum iron, however, did not increase to the normal range until after the hemoglobin had approximated the normal.

and one-half months. The serum iron, ${ }^{8}$ meanwhile, slowly increased from a basal value of 30 to 40 micrograms per cent to 60 to 70 micrograms per cent, the latter being within the normal zonal range. "Easily split-off" iron changed only from 1.7 to $2.0 \mathrm{mgm}$. per cent (as determined with $0.1 \mathrm{~N} \mathrm{HCl}$ ), both of which figures are within the limits established for normal.

The second experiment to be presented in detail (Figure 4) was performed on H. S., a 45 year old woman with hypochromic microcytic anemia and an histamine refractory achlorhydria. This patient was given 1.2 grams ferrous sulphate

3 Whenever blood was to be withdrawn for iron analyses, the iron dosage was omitted during the 24 hour period prior to venepuncture. in capsules daily during the early period of study, and 6 grams of iron and ammonium citrate daily during the last six weeks of observation. A reticulocytosis (to 10 per cent) developed following the institution of iron therapy, and the hemoglobin rose from 6 to 12 grams per cent. The basal " easily split-off" iron values were approximately $2.0 \mathrm{mgm}$. per cent (as determined with $0.1 \mathrm{~N} \mathrm{H}_{2} \mathrm{SO}_{4}$ ), that is, below normal. Blood for iron analyses ${ }^{3}$ was taken at weekly intervals. The "easily split-off" blood iron was still approximately $2.0 \mathrm{mgm}$. per cent in the specimen taken six days after the commencement of iron therapy, but by the end of the second week, it had practically doubled in value. No significant change from this higher figure occurred throughout the rest of the experiment. This in- 


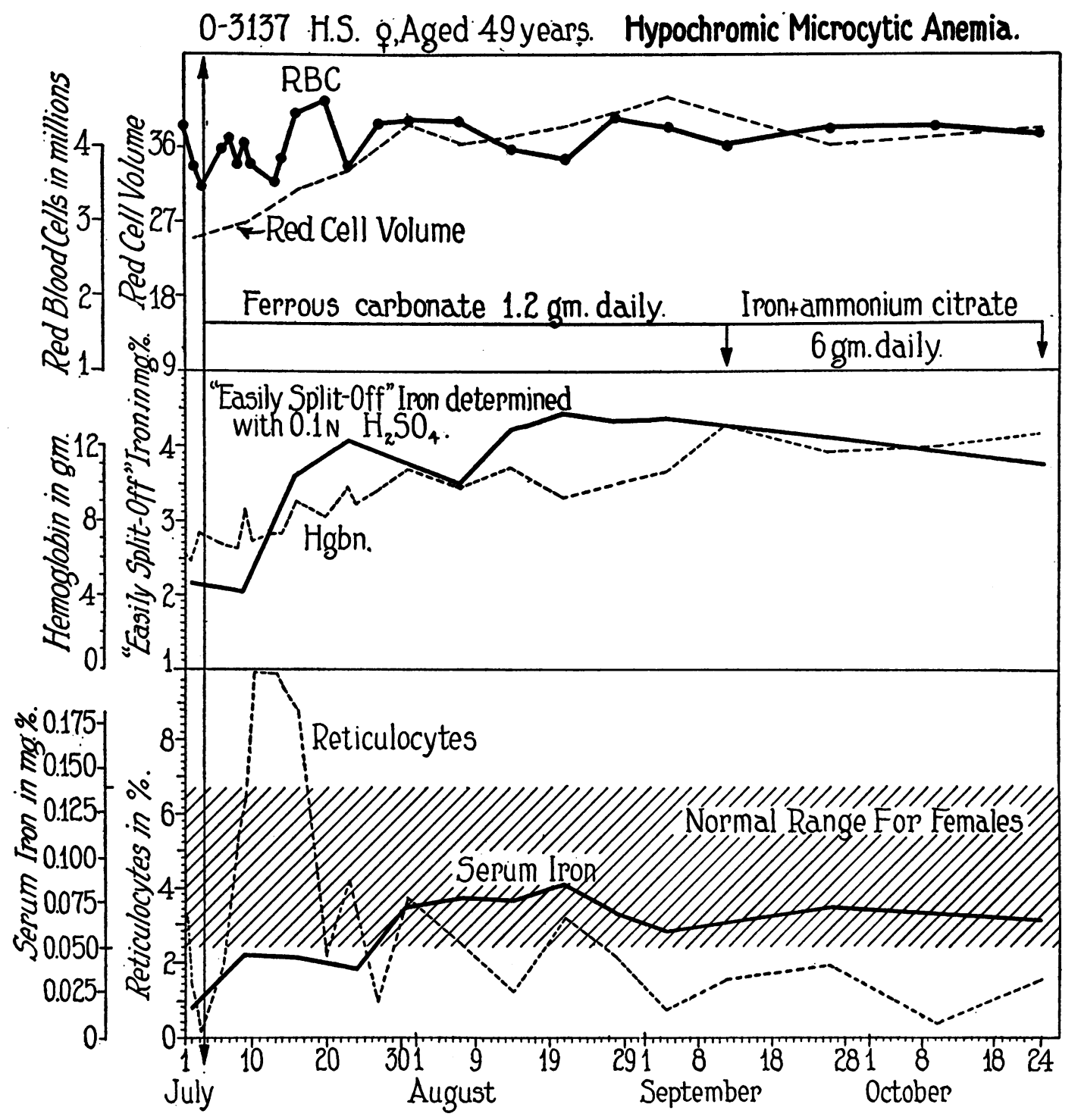

Fig. 4. Blood Iron Relationships in a Patient with Hypochromic, Microcytic Anemia During a Period of Intensive Iron Therapy

The "easily split-off" iron increased to the normal zonal range before any substantial rise in hemoglobin had occurred. Serum iron rose to normal only after the hypochromia of the red cells had been corrected.

crease was in line with the previously mentioned observation by Barkan $(15, a)$ that animals with initially low " easily split-off" blood iron values may show a rise to normal under the influence of oral iron medication, whereas no change occurred in those in whom the level initially was within normal limits. The serum iron curve, however, proceeded quite independently and reached the normal zonal range for females only after an ad- ditional two weeks of therapy-at a time when both the mean corpuscular volume and the mean corpuscular hemoglobin concentration had likewise become normal. In other words, the plasma or serum iron did not return to normal until after the hypochromia of the red cells had disappeared, the iron deficiency state had been corrected, and the bone marrow had settled down to a more normal state of erythrocytogenesis. 
Briefly, in the human iron deficiency states, plasma iron was found always to be low, while " easily split-off" iron was present in diminished to normal quantities. Indeed, in the moderate hypochromic microcytic anemias produced in three patients with polycythemia vera by therapeutic bleeding over a long period of time, the " easily split-off" iron values were frequently in the higher portion of the normal zonal range. Under the influence of iron therapy, plasma iron values returned to normal as the mean corpuscular hemoglobin concentration increased to normal and as the state of iron deficiency was corrected. When the initial " easily split-off" blood iron level was low, a return to the average was effected by iron therapy; otherwise, no change occurred.

\section{Acute hemorrhage}

The opportunity was afforded us on one occasion to observe the serum iron level in a middleaged physician several days following massive hemorrhage from a previously " silent" duodenal ulcer. At that time, the serum contained 71 micrograms per cent of iron. Two days later, however, the value had fallen to 35 micrograms per cent. This stimulated us to follow the blood iron relationships under the influence of phlebotomy performed as a therapeutic measure in the treatment of patients with polycythemia vera. The data from one such set of observations, made on E. E., a 47 year old white woman with previously untreated polycythemia vera, are recorded in Figure 5. During a four day period, $3450 \mathrm{cc}$. of blood were removed. The red cells fell from 10 to 6 million, the hemoglobin from 31 to 15 grams, and the hematocrit reading from 78 to 48 per cent. The serum iron level oscillated from 50 to 80 micrograms per cent for the first three days and then fell sharply to the low figure of 18 micrograms per cent. Determinations made during the subsequent two months showed a slight rise in the serum iron curve, but the lower limits of the normal zonal range were not reached. Relatively, a much smaller decrease in "easily split-off" iron (from 6.0 to $5.0 \mathrm{mgm}$. per cent) was noted during and immediately following this period of induced hemorrhages. The iron fraction continued its downward trend, however, throughout the rest of the period, and had fallen to $3,95 \mathrm{mgm}$. per cent at the end of that time.
In brief, within 48 to 96 hours following an acute hemorrhage, a fall in serum iron occurred to either a low normal or a lower than normal level. This change occurred at approximately the same time that the compensatory hyperplasia of erythroid elements in the bone marrow probably became evident. "Easily split-off” iron, however, showed no striking change at the time of hemorrhage, but fell slowly over a period of weeks thereafter. There was distinctly no correlation between the hemoglobin and the " easily split-off" iron curves.

\section{Hypoplastic anemia}

The hypoplastic anemias have been of special interest in our attempt to locate and identify transport iron in the blood because, when uncomplicated by hemorrhage, there should be no deficiency of iron, and because an hypoplastic bone marrow obviously will utilize only small amounts of iron in hemoglobin synthesis. The concentration of transport iron in the blood stream should, therefore, tend to be high if the storage depots retain their ability to supply iron to the blood while the bone marrow becomes progressively less able to utilize it.

Serum iron in the five cases of hypoplastic anemia in our series was found to vary from a high normal value of 158 micrograms per cent upward to the abnormally high value of 313 micrograms per cent (Table I). It will be noted that the highest figures obtained for serum iron were in the two cases of apparently " primary" aplastic anemia. It is of additional interest that when a remission developed in one of these patients (O. E.), his serum iron fell from its initial level of approximately 300 micrograms per cent to a normal value of 86 micrograms per cent, reflecting directly the increase in erythropoietic activity. "Easily split-off" iron was determined in only three cases. In two, the values were within normal limits; in the third (C. C.), they were below normal.

\section{Pernicious anemia}

In pernicious anemia, opportunity is afforded for the study of blood iron relationships in the same individual under markedly contrasting conditions. During a relapse, there is a variable amount of abnormal red cell destruction, dimin- 


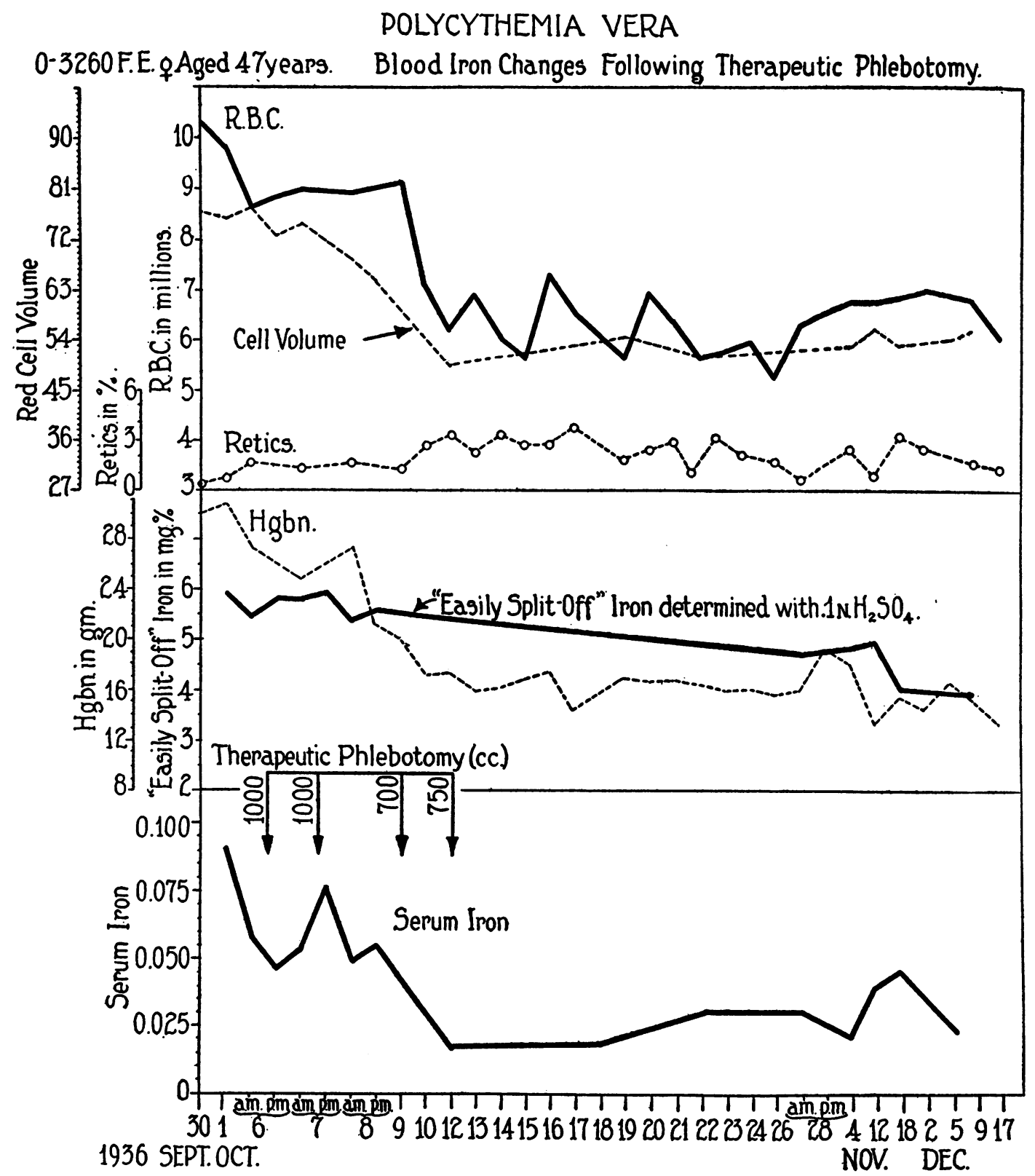

Fig. 5. Effect of Therapeutic Phlebotomy on the Blood Iron fractions in a Patient with POLYCYThemia vera

A sharp fall in the serum iron curve was obtained on the fourth day. The decrease in "easily splitoff " iron was much more gradual and continued throughout the period of observation.

ished hemoglobin synthesis as the result of maturation arrest, but no iron deficiency usually. All of these factors would tend to elevate the level of iron being transported in the blood stream. Following the institution of liver therapy, however, there is unusually rapid hemoglobinogenesis. The bone marrow might be ex- pected, under these circumstances, to require iron in relatively large quantities, and if this supply must be transported from the storage depots by the blood, the demand could conceivably be greater than the ability to respond. The transport iron concentration accordingly would tend to be lower than normal. 
In our cases of pernicious anemia in relapse (Table I), the plasma or serum iron levels were found to be uniformly high (147 to 348 micrograms per cent) whereas the "easily split-off" iron values were within normal limits with low as well as high " normals" being recorded. The series of cases studied included ten patients with Addisonian pernicious anemia, one with a macrocytic anemia which developed as the result of a food-phobia, dietary deficiency with insufficient "extrinsic factor" (Mrs. M.), and one with pernicious anemia of pregnancy (G. H.), also dietary in origin.

Soon after liver was given and slightly prior to the reticulocyte response, a precipitous drop in the concentration of serum iron from its original high value to a lower than normal level occurred in all cases. This phenomenon is analyzed in Figure 6 which tabulates the data obtained from
S. J., a 46 year old white male with typical Addisonian pernicious anemia. Determinations of blood iron were made at eight hour intervals following one intravenous injection of liver extract derived from 100 grams of raw liver. The curve of decreasing serum iron (from approximately 300 micrograms per cent to 60 micrograms per cent in 6 days) began its downward course within the first 24 hours and reached its greatest depression at the peak of the reticulocyte response, i.e. at the time of maximum delivery of young erythrocytes from the bone marrow.

To another patient with pernicious anemia (W. S., a 65 year old white male) (Figure 7) was given a suboptimal dose of liver intramuscularly. The reticulocytes rose to a peak of 36 per cent by the sixth day, and the serum iron fell from 230 to 50 micrograms per cent. Some increase in both red cells and hemoglobin oc-



Fig. 6. Effect of Liver Induced Remission on Reticulocytosis and the Serum Iron Leved 


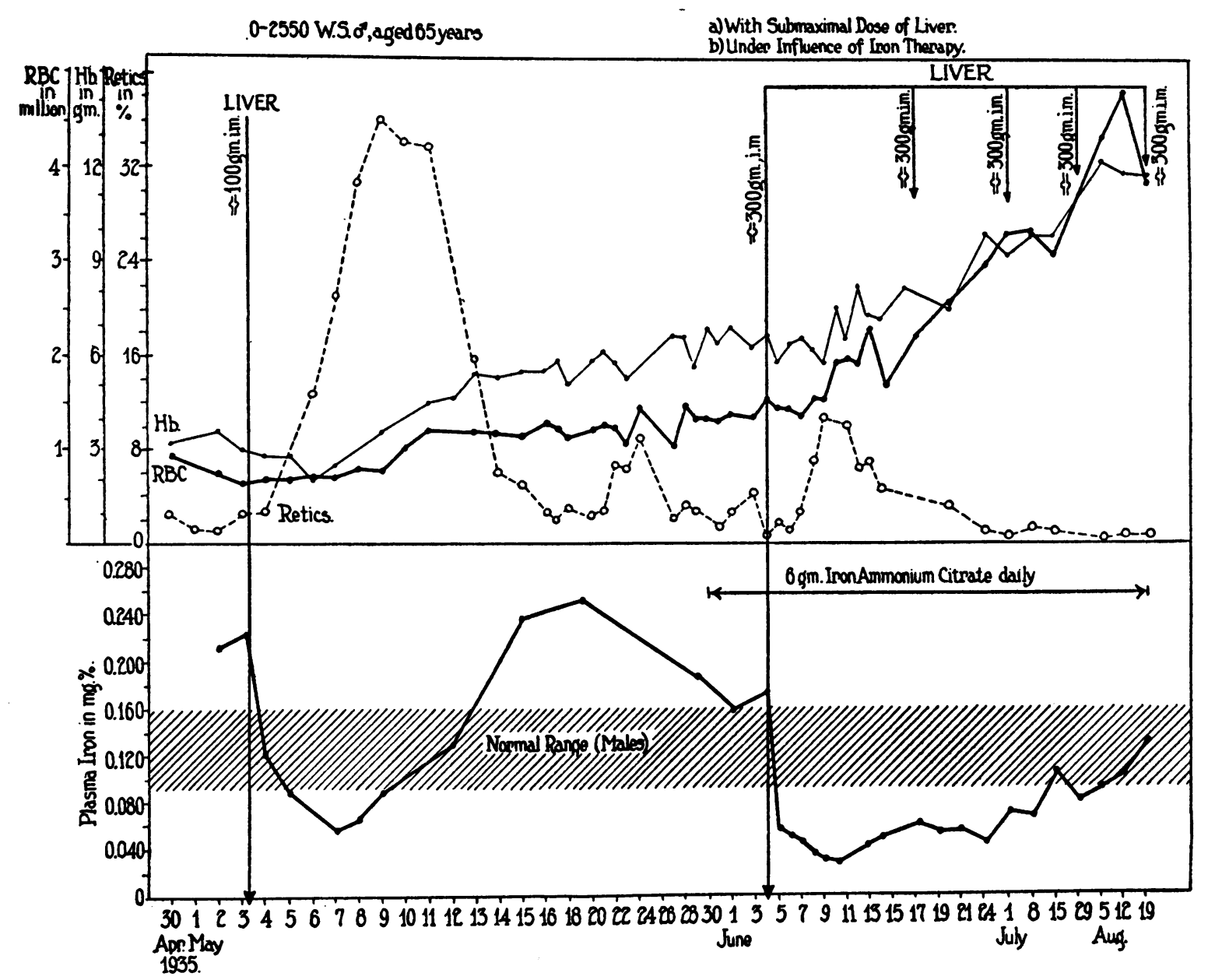

Fig. 7. Effect of Liver Induced Remissions on the Plasma Iron Level in Pernicious Anemia

curred; but as the effect of the liver became less apparent and the erythrocytes ceased to rise, the values for serum iron rose once more to the high pre-therapy level. When the administration of liver extract in adequate amounts was reinstituted, a second reticulocyte response and reciprocal fall in serum iron was observed. During this second period, six grams of iron and ammonium citrate were given daily. Care was taken to see that the iron was administered in 2 gram doses at 12 noon, 3 p.m. and 6 p.m. Blood was then withdrawn at 11:30 a.m. each day for iron analysis-after a $171 / 2$ hour " iron fast." Within two months, the erythrocytes rose to the four million level and the hemoglobin to 12 grams per cent. As the blood picture approached normal and the rate of erythrocytogenesis decreased, the serum iron promptly rose to enter the normal zonal range.
A third patient, L. R., a colored male, 52 years old (Figure 8), is presented in contrast to the previous case. This man was treated from the start with adequate amounts of liver parenterally. $\mathrm{He}$ developed a typical reticulocyte response and the characteristic precipitous fall in serum iron. His therapy was not supplemented by iron, however, and it is interesting to note that his serum iron level did not return to normal until almost a year after the beginning of the liver induced remission.

In a fourth patient, H. H. M. (Figure 9), " easily split-off" iron was determined in addition to plasma or serum iron. The irregularity of the plasma iron curve-the initial fall occurred as usual-was due to a relative refractoriness to liver therapy. It will be noted that following both the second and the third administrations of 


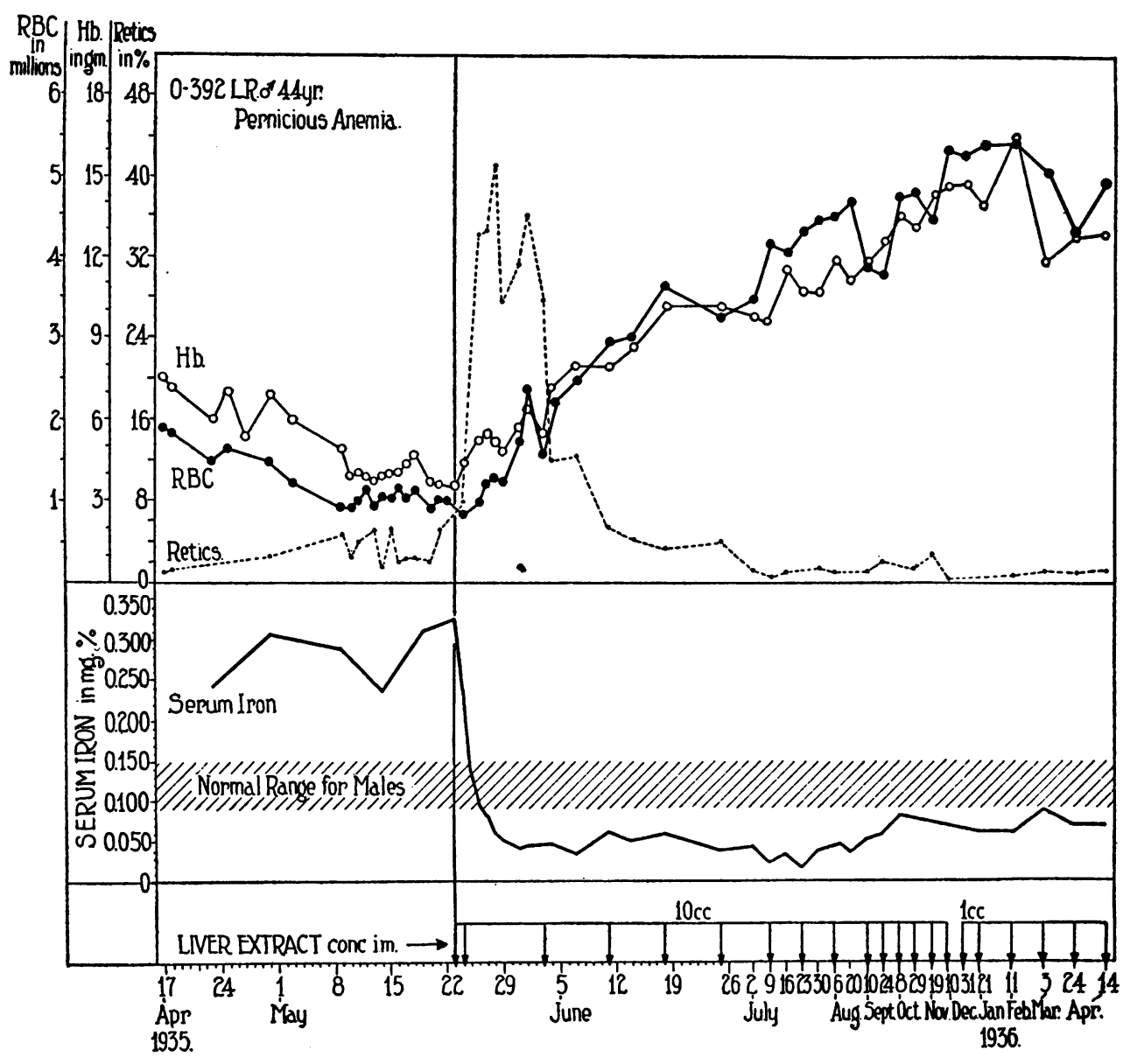

Fig. 8. Effect of Liver Induced Remissions on Serum Iron Level in Pernicious Anemia

liver, appreciable drops in serum iron were observed. The important thing in this study, by contrast, was the failure of the " easily split-off" blood iron values to show any significant changes during the entire period of observation.

G. H., the fifth case, a 22 year old white woman, presented herself during the third trimester of her fifth pregnancy with a severe anemia. The gastric acidity was normal but the diet had been grossly deficient in all essential elements including animal protein. The blood and bone marrow findings were typical of pernicious anemia with macrocytosis, megaloblastic hyperplasia, and a high serum iron. A deficiency of the "extrinsic factor" of Castle was the obvious etiological factor. When this deficiency was corrected through the institution of an adequate hospital diet supplemented by autolyzed yeast, a typical reticulocyte peak (49 per cent) was fol- lowed by a substantial increase in red cells and hemoglobin. Serial supravital differential cell counts of sternal bone marrow obtained by the puncture technique were made (Figures 10 and 11) in order to correlate the changes in bone marrow cellular equilibria with the re-equilibrations of blood iron. A precipitous fall in serum or plasma iron began within 24 hours following the institution of adequate therapy and occurred coincident with the rapid disappearance of the original megaloblastic predominance in the bone marrow. As the level of red cell maturation shifted further to the right, it became apparent that the rapid increase in normoblasts in the marrow paralleled the reticulocyte rise in the peripheral blood. As the rate of hemoglobin synthesis became accelerated, as the megaloblasts matured, the serum iron fell precipitously to the lower limits of normal. The " easily split-off" 


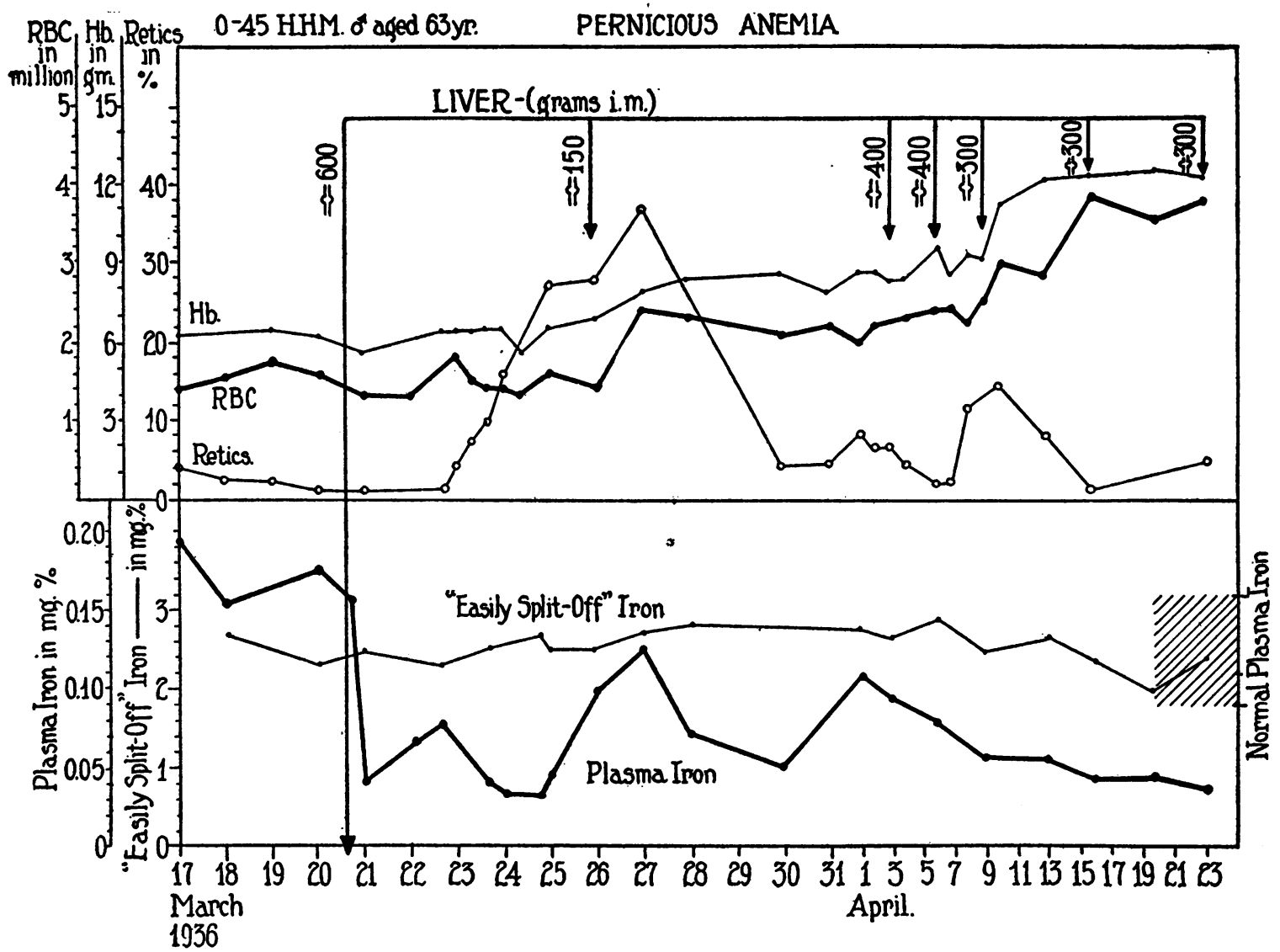

Fig. 9. Effect of Liver Induced Remission on Serum Iron and "Easily Split-off" Iron in Pernicious ANEMIA

Patient was relatively refractory to the usual dosage of liver extract.

iron increased gradually from approximately 1.4 to $2.0 \mathrm{mgm}$. per cent (determined with $0.1 \mathrm{~N}$ $\mathrm{HCl}$ ). It is interesting that the concentration of serum iron of the umbilical cord blood at the time of delivery was 247 micrograms per cent, while the serum iron in a sample of the patient's blood taken at approximately the same time was only 58 micrograms per cent. Following delivery, the red cells of the mother continued on their upward trend ultimately reaching the five million level. The hemoglobin, however, tended to lag behind more and more until a definite hypochromia of the cells developed. Iron and ammonium citrate was then given for a period of 4 weeks during which time both hemoglobin and plasma iron returned to normal.

During the greater part, at least, of the last trimester of this pregnancy, the serum iron was at a high level. Therefore, if serum iron is transport iron, as the present authors believe, the fetus was being well supplied with adequate amounts of the metal for storage in spite of the maternal anemia. Attention, likewise, is called again to the fact that the serum iron in the cord blood at birth was 247 micrograms per cent, while that in the mother's circulating blood was only 58 micrograms per cent. The infant at birth had only 4.2 million red cells and 15 grams of hemoglobin, but within 48 hours the red cells had risen (presumably as the result of dehydration) to nearly 7.0 million and the hemoglobin to above 20.0 grams. This high level was maintained for three days, and then the usual gradual fall in erythroid elements occurred. Within a month after birth, the red cells had decreased to 4.5 million and the hemoglobin to 12.5 grams. Counts obtained during the subsequent two and a half months were slightly above these "low" 


\section{PERNICIOUS ANEMIA \\ OF PREGNANCY.}

DIETARY DEFICIENCY OF"EXTRINSIC

FACTOR".

0-3097 G.H.o.Aged 21 years.

para five.
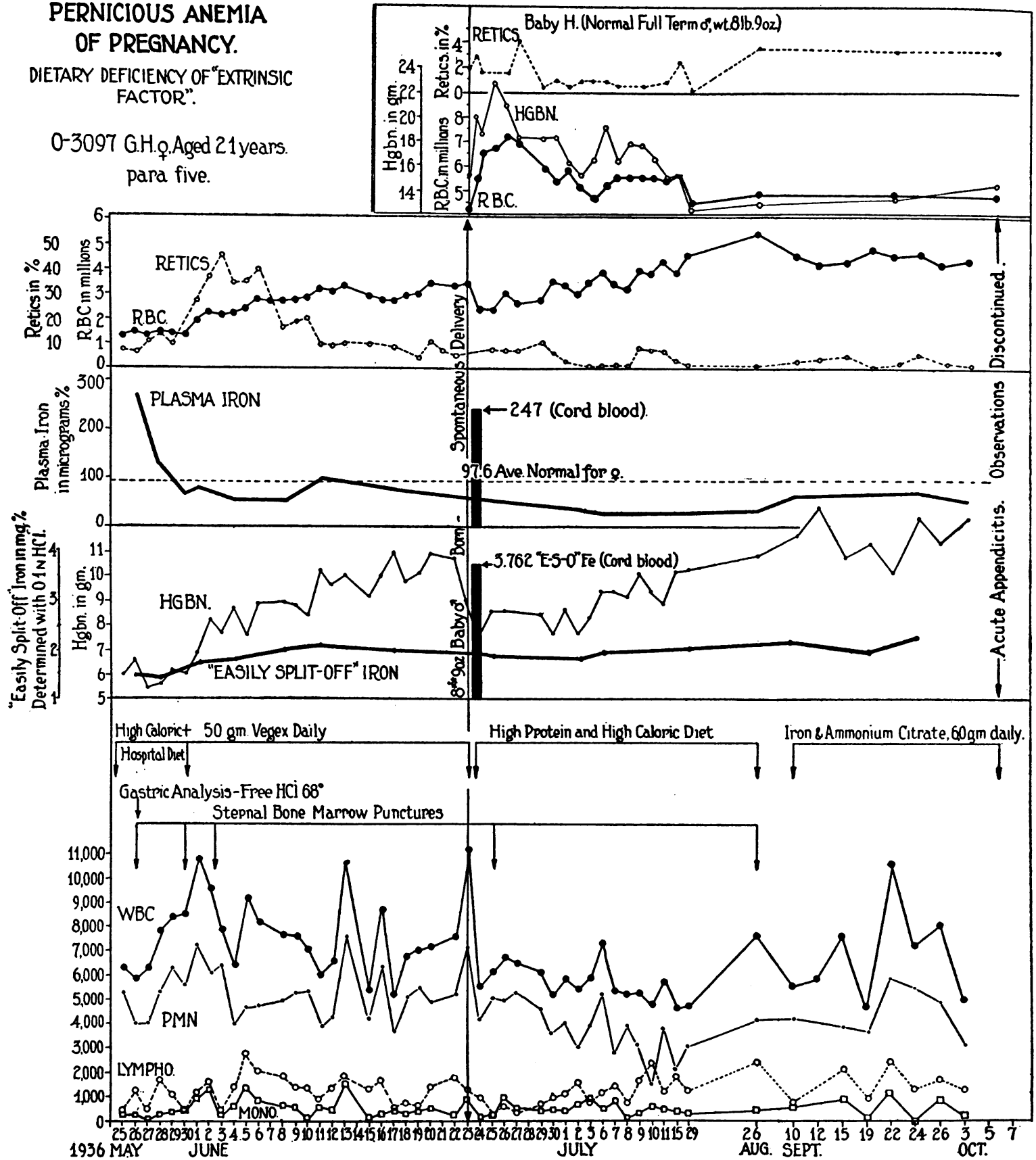

Fig. 10. Relationship of Plasma and "Easily Split-off" Blood Iron Following the Institution of Specific Therapy in a Young Woman with Pernicious Anemia of Pregnancy

Note that the fall in plasma iron preceded the development of a reticulocytosis, and that the "easily split-off" iron gradually increased in value as the erythroid function returned to normal in the peripheral blood.

values. It is interesting to observe that at birth a macrocytosis with moderate variation in size and shape of the cells and a high color index were present. The fact that fall in red cells and hemo- globin was no greater than that which occurs in infants born of " normal" mothers constitutes important clinical evidence tending to substantiate the assumption made above-that adequate 


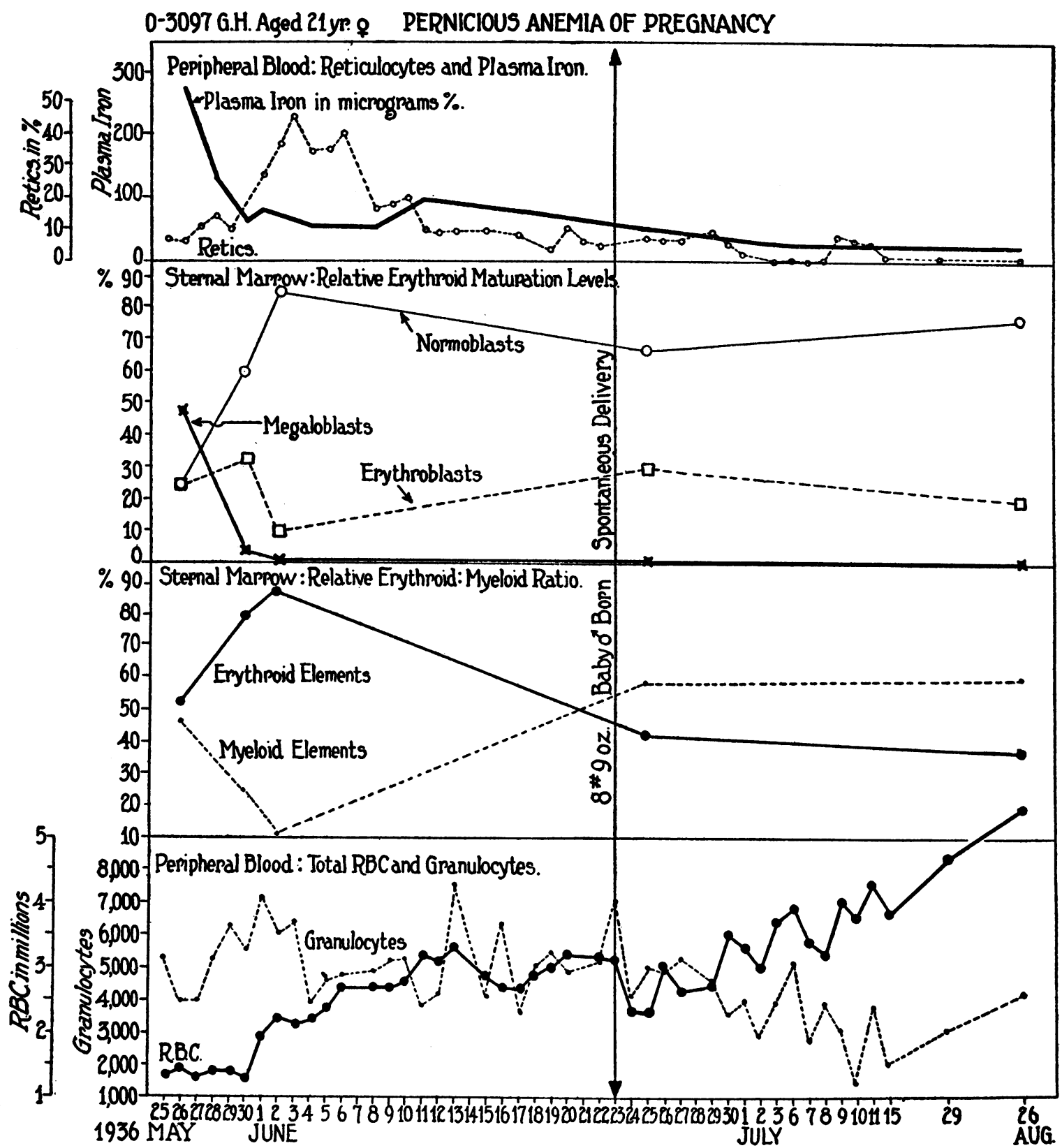

Fig. 11. Further Analysis of Serum Iron, Bone Marrow, and Changes in Peripheral Blood Cells in the Case Presented in Figure 10

The fall in serum iron paralleled the disappearance of megaloblasts from the bone marrow and occurred coincident with the reinstitution of normal erythrocyte maturation and hemoglobin synthesis.

amounts of iron had been made available, through the elevated serum iron, to the fetal organism for storage.

Several less complete studies of the blood iron relationships in pernicious anemia have been made by other investigators. Erben in 1900 (24) and
Fowell in 1912 (25) reported that they had found the non-hemoglobin iron increased in pernicious anemia. Riecker $(8, a)$ observed a high serum iron level in most of his cases and noted that after induced remissions these values returned to normal. Attention has been called (17) 
however, to the fact that the serum iron values reported by Riecker are considerably higher than those obtained in more recent investigations. Dominici (16) obtained values for the "easily split-off" blood iron fraction of from 1.34 to 2.08 mgm. per cent (determined with $\mathrm{H}_{2} \mathrm{SO}_{4}$ ), values with which our own figures are in close agreement.

\section{The hemolytic states}

In hemolytic states, another excellent opportunity for the study of iron in the blood is provided. With an increase in red blood cell destruction, a greater amount of iron from the released hemoglobin is poured into the blood stream for transportation to organs of storage, utilization, and excretion. At the same time, the erythropoietic elements in the bone marrow are stimulated to increased activity, and extract iron from the blood for the synthesis of hemoglobin at an unusually rapid rate. The amount of transport iron present in the blood at any given time must, consequently, depend on the balance which may be struck between these two abnormally stimulated mechanisms of hemolysis and erythrogenesis. One would expect, therefore, that single isolated determinations of the various forms of blood iron in patients presenting hemolytic phenomena would yield little valuable information-and such has proved to be the case. In patients with congenital hemolytic icterus, for instance, both serum and "easily split-off" iron values were found to lie within their respective normal zonal ranges (Table I). Occasionally, the concentration of serum iron was a little higher than normal. Dominici (16) has reported " easily split-off" iron levels in three cases of hemolytic icterus. One of these was higher than was found in any of his control subjects; the other two were well within the limits for normal.

The detailed study of individual cases, on the other hand, has yielded most interesting confirmatory data. Following splenectomy in patients with congenital hemolytic icterus, an immediate fall in the serum iron level was noted (Table I). In the instance of B. B., a young woman 26 years old, with congenital hemolytic jaundice (Figure 12), the serum iron immediately before operation was 160 micrograms per cent. Twenty minutes after splenectomy had been performed, the serum iron concentration had fallen to 80 micrograms per cent. This fall in serum iron level continued throughout the first two postoperative days until a low level of 30 micrograms per cent was reached. As the reticulocytes fell gradually from their preoperative high level, however, the serum iron again equilibrated, returning to within the normal limits. Following splenectomy, the abnormal destruction of erythrocytes abruptly ceased, and with this source of iron to the serum or plasma stopped, the serum iron decreased to the level at which it would have been preoperatively, because of the increased bone marrow activity, had not the spleen been pouring into the blood stream large amounts of iron from the released hemoglobin. As the bone marrow once more became capable of supplying an adequate number of erythrocytes, and normal cellular equilibration was resumed, the serum iron returned to a normal level.

Another series of observations were made on E. S., a 46 year old white male with polycythemia vera, in whom intravascular hemolysis was produced by phenylhydrazine hydrochloride (Figure 13). This patient, prior to the studies described here, had been treated by therapeutic phlebotomy. The red cells, consequently, were hypochromic, and the concentration of serum iron was low (25 to 40 micrograms per cent). During the period of most rapid hemolysis, characterized by a rapid fall in erythroid elements and by an increasing reticulocytosis, the serum iron increased to twice its basal level. "Easily split-off" iron decreased slightly with the drop in red cells, but remained constantly within the limits for normal. When the rate of hemolysis diminished and the red cells began again their upward climb, serum iron returned to its pre-therapy level.

\section{The possibility of an exchange of iron between "Easily split-off" and plasma blood iron fractions}

The strongest experimental evidence to support Barkan's hypothesis that "easily split-off" blood iron is transport iron and that the iron in plasma merely serves as the direct medium of exchange between it and the tissues comes from his reported observations to the effect that with the incubation of whole blood at $37.5^{\circ} \mathrm{C}$. an increase 









Fig. 13. The Effect of Phenylhydrazine Hydrochloride on the Circulating Erythron and Blood Iron RELATIONSHIPS

Note that the period of maximum hemolysis was characterized by a rise in the reticulocytes and in the plasma iron.

in plasma iron occurs $(15, b)$. Barkan employed the intravenous injection of sodium polyanetholsulphonate 4 to make the blood of his experimental animals non-coagulable. He then collected two samples of blood. The plasma from one of these was immediately separated by centrifugation and analyzed for non-hemoglobin iron. The other specimen was incubated for six hours at body temperature and then treated in the same way. In the majority of instances, a substantial

4 Sodium polyanetholsulphonate is an organic anticoagulant supplied by the Hoffman-La Roche Company under the trade name "Liquoid." It is used to inhibit blood coagulation in experimental animals, is active in vitro and, when administered intravenously, in vivo as well. The toxicity of the drug is demonstrated by the fact that doses of 0.02 gram or more per kilogram of body weight are fatal to the rabbit. increase (e.g. 150 to 250 micrograms per cent) in' plasma iron was observed.

We have repeated these observations on both dogs and human subjects (Table II). With the former, "Liquoid" (La Roche) was used, just as in Barkan's experiments. Human blood was prevented from coagulating by being collected in flasks containing appropriate amounts of isotonic, iron-free potassium oxalate. Determinations of plasma iron were made both by digesting whole plasma in which the hemoglobin iron concentration had been estimated by the micro-benzidine method (17), and by dialysis of the plasma through cellophane membranes and subsequent digestion of the dialysate. In no case have we been able to detect an increase in non-hemoglobin plasma iron after incubation of whole blood at $37.5^{\circ} \mathrm{C}$. for 6 hours. If a transfer of iron from 
TABLE II

Failure of iron to be transferred from erythrocytes to plasma when whole blood was incubated "in vitro" at $37.5^{\circ} \mathrm{C}$.

\begin{tabular}{|c|c|c|c|c|c|c|c|c|c|}
\hline \multirow{3}{*}{ Subject } & \multirow{3}{*}{ Anticoagulant } & \multicolumn{6}{|c|}{ Plasma iron determined by digestion of whole plasma } & \multirow{2}{*}{\multicolumn{2}{|c|}{$\begin{array}{l}\text { Plasma iron determined after dialysis } \\
\text { (acidified with 0.1N HCl) }\end{array}$}} \\
\hline & & \multicolumn{3}{|c|}{$\begin{array}{c}\text { Before } \\
\text { incubation }\end{array}$} & \multicolumn{3}{|c|}{$\begin{array}{l}\text { After incubation at } \\
37.5^{\circ} \mathrm{C} \text {. for } 6 \text { hours }\end{array}$} & & \\
\hline & & $\begin{array}{l}\text { Total } \\
\text { iron }\end{array}$ & $\mid \begin{array}{c}\text { Hemoglo- } \\
\text { bin iron }\end{array}$ & $\begin{array}{c}\text { Non- } \\
\text { hemo- } \\
\text { globin } \\
\text { iron }\end{array}$ & $\begin{array}{c}\text { Total } \\
\text { iron }\end{array}$ & $\begin{array}{l}\text { Hemo- } \\
\text { glo- } \\
\text { bin } \\
\text { iron }\end{array}$ & $\begin{array}{c}\text { Non- } \\
\text { hemo- } \\
\text { globin } \\
\text { iron }\end{array}$ & $\begin{array}{c}\text { Before } \\
\text { incu- } \\
\text { bation }\end{array}$ & $\begin{array}{l}\text { After incubation } \\
\text { at } 37.5^{\circ} \mathrm{C} \text {. for } \\
6 \text { hours }\end{array}$ \\
\hline & & $\underset{\substack{\text { mpm. } \\
\text { per }}}{\cos .}$ & $\underset{\substack{m g m . \\
\text { per }}}{\operatorname{mgm} .}$ & $\underset{\substack{\text { mgm. } \\
\text { per }}}{\operatorname{mer}}$ & $\underset{\substack{m g m . \\
\text { per } \\
c e n t}}{\operatorname{men}}$ & $\underset{\substack{\operatorname{mgm} \\
\text { per }}}{\operatorname{men}}$ & $\underset{\substack{m g m . \\
\text { per }}}{\operatorname{men}}$ & $\underset{\text { per }}{m g m .}$ & mgm. per cent \\
\hline Dog. & “Liquoid" (i.v.) & & & & & & & 0.231 & 0.244 \\
\hline & "Liquoid" (i.v.) & 0.201 & 0.010 & 0.191 & 0.200 & 0.005 & 0.195 & 0.190 & 0.234 \\
\hline W. R.A. "Normal" $"$ " & $\begin{array}{l}\text { Isotonic oxalate } \\
\text { Isotonic oxalate }\end{array}$ & 0.088 & 0.002 & 0.086 & 0.090 & 0.005 & 0.085 & 0.120 & 0.124 \\
\hline C. V. M. "Normal" o".. & Isotonic oxalate & 0.099 & 0.002 & 0.097 & 0.125 & 0.020 & 0.105 & 0.102 & $\begin{array}{l}0.104 \\
(0.118 \text { after incubation at } \\
37.5^{\circ} \mathrm{C} \text {. for } 24 \text { hours. } \\
\text { Gross hemolysis present. })\end{array}$ \\
\hline 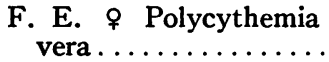 & Non & 0.036 & 0.001 & 0.035 & 0.039 & 0.002 & 0.037 & & \\
\hline E. S. Polycythemia vera & Isotonic oxalate & 0.031 & $<0.001$ & 0.031 & 0.036 & 0.002 & 0.034 & & \\
\hline$\sigma_{V}^{\top} \ldots \ldots \ldots \ldots \ldots$ & Isotonic oxalate & 0.042 & 0.006 & 0.036 & 0.093 & 0.049 & 0.044 & & \\
\hline$\sigma^{\circ}$ & Isotonic oxalate & 0.037 & $<0.001$ & 0.037 & 0.043 & 0.004 & 0.039 & & \\
\hline
\end{tabular}

the " easily split-off" iron fraction to the plasma occurs, one would certainly expect it to be particularly manifest in cases of polycythemia vera in whom relative iron deficiencies had been produced by therapeutic bleeding. Under these circumstances, plasma iron was lower than normal, while "easily split-off" blood iron was either well within normal limits or at a high level. Our observations in normal animals and in normal human subjects have been supplemented with determinations in three such cases of polycythemia vera, and again no increase in non-hemoglobin plasma iron was observed.

It is not possible to argue that an exchange between the "easily split-off" and plasma blood iron fractions does not occur in vivo; but since such an exchange cannot consistently be demonstrated by in vitro observations, the possibility seems less probable.

\section{SUM MARY}

A brief summary of the changes effected in the plasma and " easily split-off" forms of blood iron by various endogenous and exogenous stimuli described in the experimental portion of this paper is given in Table III. Plasma or serum iron was found to be very labile. In the iron deficiency states, it was uniformly low. Under conditions of decreased red cell formation (e.g. hypoplastic anemia and pernicious anemia in relapse), it tended to be high. When the bone marrow was stimulated to unusually active erythrocytogenesis (e.g. following acute hemorrhage and liver induced remission in pernicious anemia), the plasma iron concentration was low. In the hemolytic states, the plasma iron was found to be in equilibrium between the amounts of iron being added to the blood stream as a result of the hemolytic process, and the amount being withdrawn by the hyperplastic bone marrow. When the equilibrium was disturbed by splenectomy in congenital hemolytic icterus, the plasma iron fell to a level consistent with the rate of rapid hemoglobin synthesis. During the most active period of a phenylhydrazine induced hemolysis, the plasma iron increased in value. Following the administration of single large doses of iron salts by mouth, the concentration of iron in plasma was increased frequently to from three to ten times its basal level. Plasma iron was affected by these various influences, in other words, exactly as one would expect transport blood iron to be affected. A single graphic representation of these interrelationships is presented in Figure 14. 
TABLE III

Summary of plasma iron and "easily split-off" iron changes which relate to the question of transport iron identity

\begin{tabular}{|c|c|c|}
\hline 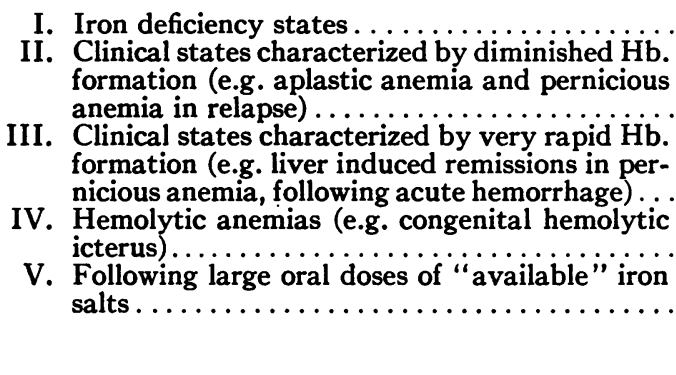 & $\begin{array}{l}\text { Low } \\
\text { High } \\
\text { Low } \\
\text { Normal to high } \\
\text { Increased } 3 \text { to } 10 \\
\text { timesover basal } \\
\text { level }\end{array}$ & $\begin{array}{l}\text { Lower than normal and normal values } \\
\text { Lower than normal and normal values } \\
\text { Normal (high as well as low normal values) } \\
\text { Normal } \\
\text { No change from basal level (except slight in- } \\
\text { crease reflected from plasma iron increase) }\end{array}$ \\
\hline
\end{tabular}

"Easily split-off" blood iron, on the other hand, proved to be relatively stable. In the iron deficiency states, it was either normal or lower than normal. Under conditions of depressed hemoglobin synthesis and diminished erythrocytogenesis, it was just as likely to be low-normal as it was to be high-normal. No.significant changes occurred in the fraction in patients with pernicious anemia after liver therapy. "Easily split-off" blood iron was not obviously influenced by increased rates of red cell destruction, and it did not show true increases following the administration of single oral doses of iron salts. Iron therapy in patients with iron deficiency states and slightly low " easily split-off" iron values was attended by an increase in the "easily split-off" fraction to normal levels; but this increase was relatively independent of the changes in plasma iron and erythroid elements. Low values for " easily split-off" iron occurred primarily in those anemic states in which the circulating erythroid elements were markedly decreased (particularly with hemoglobin levels of less than 5.0 or 6.0 grams). However, it is obvious from the studies following acute hemorrhage and from those fol-

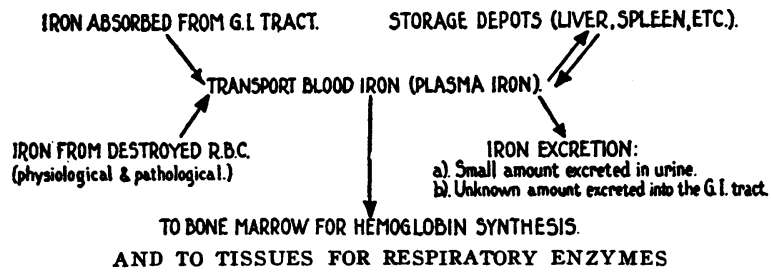

FIG. 14 lowing remissions induced by liver in pernicious anemia that no direct relationship holds between concentrations of hemoglobin and " easily splitoff " iron. Investigations aimed at defining more sharply the relationship, if any, between hemoglobin and "easily split-off" blood iron are in progress.

An exchange of iron from the " easily splitoff " to the plasma iron fraction was not observed after incubation of unclotted blood at $37.5^{\circ} \mathrm{C}$. for 6 to 8 hour periods.

\section{CONCLUSIONS}

1. Iron is transported as plasma iron. The quantity present in peripheral blood is influenced by, and is a measure of : (a) The amount of iron being absorbed from the gastro-intestinal tract; (b) The extent and adequacy of the iron reserves of the body; (c) The ability of the bone marrow to utilize iron in the synthesis of hemoglobin; (d) The rate of hemoglobin synthesis; (e) The extent of hemolysis taking place in spleen and other tissues; and $(f)$ The physiological or pathological equilibrium existing between $(d)$ and (e).

2. The physiological function of " easily splitoff " blood iron remains yet to be defined.

\section{BIBLIOGRAPHY}

1. Macallum, A. B., On the distribution of assimilated iron compounds other than hemoglobin and haematins, in animal and vegetable cells. Quart. J. Micr. Sc., 1895, 8, 175.

2. Ehrlich, P., and Lazarus, A., Die Anaemie. Noth- 
nagel's Handb. spec. Path. u. Therap., Alfred Hölder, Wein, 1898, 8, 11.

3. Proescher, F., and Arkush, A., On the pathology of iron. J. Lab. and Clin. Med., 1928, 13, 807.

4. Henriques, V., and Roche, A., Sur le fer du sérum sanguín de diverses espèces animales. Bull. Soc. Chim. biol., 1927, 9, 501.

5. Marlow, A., and Taylor, F. H. L., Constancy of iron in the blood plasma and urine in health and in anemia. Arch. Int. Med., 1934, 53, 551.

6. Fontès, G., and Thivolle, L., Sur la Teneur du Sérum en Fer non-Hémoglobinique et sur sa Diminution au Cours de L'Anémie Expérimentale. Compt. rend. Soc. de biol., 1925, 93, 687.

7. Warburg, O., and Krebs, H. A., Uber locker gebundenes Kupfer und Eisen im Blutserum. Biochem. Ztschr., 1927, 190, 143.

8. Riecker, H. H.,

(a) Iron metabolism in pernicious anemia and in secondary anemia. Arch. Int. Med., 1930, 46, 458.

(b) and Winters, M. E., Serum iron determinations applied to the study of experimental anemia. Am. J. Physiol., 1930, 92, 196.

9. Langer, A., Uber den Gehalt an Ferrieisen in normalen und pathologischen Seren. Biochem. Ztschr., 1931, 242, 316.

10. Guthmann, H., Brückner, M. A., Ehrenstein, and Wagner, H., Das ultrafiltrable Eisen im Serum der Frau. (Biologische und klinische Studien.) Arch. f. Gynäk., 1931, 147, 469.

11. Locke, A., Main, E. R., and Rosbash, D. O., The copper and non-hemoglobinous iron contents of the blood serum in disease. J. Clin. Invest., 1932, 11, 527.

12. Thoenes, F., and Aschaffenburg, R., Der Eisenstoffwechsel des wachsenden organismus. S. Karger, Berlin, 1934.

13. Roosen-Runge, E., Beitrag zur Methodik der Bestimmung des "leicht abspaltbaren" Eisens im Serum und einige klinische Ergebnisse. Klin. Wchnschr., $1935,14,1540$.

14. Starkenstein, E., and Weden, H., Uber das anorganische Eisen des Organismus. Arch. f. exper. Path. u. Pharmakol., 1928, 134, 274.
15. Barkan, G.,

(a) Eisenstudien. III. Die Verteilung des leicht abspaltbaren Eisens zwischen Blutkörperchen und Plasma und sein Verhalten unter experimentellen Bedingungen. Ztschr. f. physiol. Chem., 1927, 171, 194.

(b) Weitere Untersuchungen über das säurelösliche Plasmaeisen. Ztschr. f. physiol. Chem., 1936, 239, 97.

16. Dominici, G., La determinazione quantitativa del ferro inorganico del sangue. Arch. per le sc. med., 1929, 53, 538.

17. Moore, Carl V., Studies in iron transportation and metabolism. I. Chemical methods and normal values for plasma iron and "Easily split-off" blood iron. J. Clin. Invest., 1937, 16, 613.

18. Barkan, G., and Berger, E., Differenzierung des leicht abspaltbaren Bluteisens auf Grund seiner Reaktion mit Kohlenoxyd und Sauerstoff. Arch. f. exper. Path. u. Pharmakol., 1928, 136, 278.

19. For complete reference to Barkan's work, see Bibliography to the preceding paper.

20. Lintzel, W.,

(a) Zur Frage des Eisenstoffwechsels. I. Das Verhalten des Blutfarbstoffes bei künstlicher Verdauung. Ztschr. f. Biol., 1925, 83, 289.

(b) and Radeff, T., Uber die Hämatinbildung aus CO-Hämoglobin und Oxyhämoglobin durch verdünnte Säuren. Biochem. Ztschr., 1928, 203, 212.

21. Bing, F. C., Hanzal, R. F., and Myers, V. C., Hypersideremia following the oral administration of iron. J. Biol. Chem. (Proc.), 1935, 109, viii.

22. Barkan, G., Eisenstudien. VII. Uber das Verhalten von anorganischem Eisen nach Zusatz zum Blute. Ztschr. f. physiol. Chem., 1933, 216, 17.

23. Barkan, G., VI. Uber Bestimmungsmethodik und Eigenschaften des "leicht abspaltbaren" Bluteisens. Ztschr. f. physiol. Chem., 1933, 216, 1.

24. Erben, F., Die chemische Zusammensetzung des Blutes bei perniciöser Anämie. Ztschr. f. klin. Med., 1900, 40, 267.

25. Fowell, P. H. C., Iron in the blood. Quart. J. Med., 1912, 6, 179. 